\title{
Knowledge of Sports Teachers in a Rhythmic Gymnastics Training Program
}

\section{Christina Fajar Sri Wahyuniati ${ }^{1}$, Furqan Hidayatullah¹, Sapta Kunta Purnama ${ }^{1}$, and Siswanyoto Siswanyoto ${ }^{2}$}

${ }^{1}$ Sports Science Department, Doctoral Program, Universitas Sebelas Maret Surakarta

${ }^{2}$ Universitas Negeri Yogyakarta

ORCID:

Christina Fajar Sri Wahyuniati: https://orcid.org/0000-0002-3979-6590

\section{Abstract}

The purpose of this research was to examine the level of knowledge of sports teachers in the rhythmic gymnastics training program in the Special Region of Yogyakarta. This was descriptive research and data were collected through a questionnaire. Purposive sampling was used and the sample size was 24 . Data were analyzed though descriptive statistics. The results showed that the level of knowledge of sports teachers in the rhythmic gymnastics training program were as follows: $54.2 \%$ in the top level (excellent),

Corresponding Author: Christina Fajar Sri Wahyuniati fajar@uny.ac.id

Published: 29 December 2021 Publishing services provided by Knowledge E

(c) Christina Fajar Sri Wahyuniati et al. This article is distributed under the terms of the Commons Attribution License, which permits unrestricted use and redistribution provided that the original author and source are credited.

Selection and Peer-review under the responsibility of the ICMEd Conference Committee.

\section{G OPEN ACCESS} $41.7 \%$ in the second level, $4.2 \%$ in the third level, and $0 \%$ in the bottom level. Based on these results, it can be concluded that the level of knowledge of these sports teachers is acceptable.

Keywords: sports teachers, coaches, rhythmic gymnastics, training program

\section{Introduction}

Gymnastics is a significant physical activity to optimize a child's growth and development. Rhythmic gymnastics is a sport that brings together some aspects of both the potential art of expressive movement through body techniques and equipment, relating to the perception and appearance of the song [1]. Gymnastics movement stimulates the development of physical fitness components, such as muscle strength and endurance from all parts of the body. Therefore, physical fitness is an essential indicator of a person's health status as well as the quality of life [2]. Strength, speed, flexibility, skill, and stamina or muscle endurance are the gymnast's primary physical abilities. Heavy work to realize flexibility, durability, balance, motor coordination, rhythm, and excellent skills require high [3]. Composition and coordination of the body are considered a prerequisite at a high level, and motion coordination has high stability as an indicator of talent in the selection of athletes [4].

Early age is a period of growth and development that is important for later life. Positive signs of growing interest in the field and the need to respond to the need to be 
competent in the challenge of assessing clinical testing [5]. Therefore, at this time, all the potential that children have needs to be encouraged so that it will develop optimally. The results of the study are necessary to limit exercise balance in children because gastrocnemius medial (GM) and gastrocnemius lateral (GL) activities are performed excessively [6]. The age of elementary school children in their characterization of physical growth has reached maturity; they have been able to control their body and balance. Also, the development of children from the social side, especially children who are in the early grades of elementary school, they can show their respect about their gender, start competing with peers, have friends, be able to share, and be independent. Some studies have concluded that children start gymnastics earlier than other sports, and that exercise is already devoted to the youngest age of 9 [7].

Teaching and practicing rhythmic gymnastics can be done by a sports teacher or gymnastics coach. Model imitation, model group learning, and play stimulation to improve motor manhood can be done in between by being given necessary skills for writing and drawing, exercise skills or using exercise tools, movement movements, such as jumping up and running, and line-ups. Rhythmic gymnastics in performing the whole activity must match the rhythm that accompanies it. Rhythmic gymnastics can be performed without tools or with tools held, such as balls, ropes, sticks, up to, and mace. Rhythmic gymnastics demands the head, arms took, and legs move in harmony with the accompanying rhythm.

Gymnastics is a sport in which there is a physical activity with movement that prioritizes flexibility/ flexibility, either with or without music participate in physical activity, can prevent the onset of disease and gain gains in physical fitness [8]. In addition to health, Currently, Health Education is a top priority [9]. Gymnastics is also contested in regional, national, and international competitions. In order to verify the quality of assessments in rhythmic gymnastics, it is necessary to objectively identify the assessment system [10], determine the extent of the assessment system, and can provide objective verification of judging quality in rhythmic gymnastics [10]. Federation Internationale de Gymnastique describes various gymnastics, namely 1) general gymnastics, 2) artistic gymnastics, 3) rhythmic gymnastics, 4) trampoline gymnastics, 5) aerobic gymnastics, and 6) acrobatic gymnastics. The categories of gymnastics contested in Indonesia are rhythmic gymnastics, men's artistic gymnastics, women's artistic gymnastics, and aerobic gymnastics under Federation Internationale de Gymnastique.

Rhythmic gymnastics belongs to the category of individual sports, where techniques in gymnastics are not easy to master; this is because movement in rhythmic gymnastics requires good skills, motor skills are a must-have and are a must-have important in 
the early phases of the exercise process [11]. The main goal of rhythmic gymnastics in a match is to create high scores by minimizing the error rate of activity. Some research has been done about the characteristics, knowledge, and abilities that must be possessed by the rhythmic gymnastics referee so that his judgment can be accurate [12].

High levels of motion difficulty contribute to getting the most value. As for rhythmic activity, there are three things to note: flexibility, continuity, and accuracy with rhythm. Movement in rhythmic gymnastics aims to relax the muscles of the body, expand the joint exercise, eliminate muscle injuries, improve health, and physical fitness, aspects of physical fitness as the basis in the formation of technical skills in sports [13].

The concept of motion mastery in rhythmic gymnastics needs to practice a technique or engineering skills and understanding in the idea to be applied to every training and match situation, an important aspect in good coaching through monitoring and controlling training loads [14]. The concept of knowledge of basic techniques in rhythmic gymnastics is jump, pivot, and balance Rhythmic gymnastics athletes should be able to perform some upward jumping movements, changing motion, posture, and body lock [15]. The idea of mastery of techniques in using sports engineering skills needs to be oriented towards the achievement of each skill mastered by the athlete, the initial phase of the training process on which motor skills and skills are based [11].

Assessment of engineering skills is carried out by a sports teacher or trainer, so as to understand and be able to see the progress of the students' training with the training program of the sports teacher and gymnastics coach, an important aspect in effective coaching through controlling and monitoring the right load. [14]. Assessments should be carried out continuously and can be carried out during training and matches to assess the successful use of mastered rhythmic gymnastics skills. Whether it's a gymnast's appearance, one of them is a coach or a sports teacher based on the accuracy of the authenticity of the movements made by the [16]. Sports coaches or teachers play an essential role in preparing athletes to make the most of the training program. Trainers or Sports teachers should know about the preparation of training programs and the division of exercise periodization as determinants of athlete achievements.

Good coaches are coaches who can master a wide range of competencies of coaches, one of which is knowing and being able to develop training programs in the gymnastics in particular. Coaches do not seek information regarding the preparation of the training program. Still, they should be able to combine the story and then apply it to gymnasts by following the applicable rules. The fact that there are still many coaches in Yogyakarta Special Region Province has not fully mastered the role of coach as the constituent and manager of the training program. From the observations that the 
researchers conducted, several coaches make exercise programs during the training process. At the same time, the achievements of athletes are influenced by the skill factor of the coach in compiling an exercise program based on science. Coaches in the Special Region Province of Yogyakarta generally have backgrounds from practitioners, academics, and the public.

Sports is a physical activity that is needed by the community, so many people are found doing physical activity. Modern people's lives today are inseparable from sports activities both to improve achievement and to maintain body fitness. However, there are still many less mobile people, so they need additional physical activity to maintain body fitness. Indonesian Law No. 3/2005 on the National Sports System states that sports are divided into three: educational sports, recreational sports, and sports Achievements. The sporting institution that oversees sports coaching achievement is the National Sports Committee (KONI), the parent organization of sports, clubs, or associations. Sports coaching is a significant factor for continuity in the regeneration of athletes in sports. Coaching gymnastics in Indonesia has a vital role in sports associations and society.

Looking at the problems that researchers described above, research needs to be done to find out the level of knowledge of rhythmic gymnastics coaches in the Special Region Province of Yogyakarta about the training program. The hope is that every coach understands about rhythmic gymnastics training programs. Therefore, researchers are interested in researching the level of knowledge of rhythmic gymnastics coaches in the Province of Yogyakarta Special Region on rhythmic gymnastics training programs.

\subsection{The Structure}

There are several factors that affect the achievement of an athlete's achievement. One of them is the coach's ability to train his athletes $[17,18]$. Research needs to be done to find out the level of knowledge of rhythmic gymnastics coaches in the Special Region Province of Yogyakarta about the training program. The fact that there are still many coaches in Yogyakarta Special Region Province has not fully mastered the role of coach as the constituent and manager of the training program. The purpose of this research is to know the level of knowledge of sports teachers, rhythmic gymnastics coaches in the Special Region of Yogyakarta in the rhythmic gymnastics training program. 


\section{Related Works/Literature Review}

\subsection{Rhythmic Gymnastic}

Gymnastics is a sport that has several types of groups. Gymnastics is divided into six groups, namely: rhythmic, artistic, aerobic, acrobatic, trampoline and general gymnastic [19]. Rhythmic gymnastics is gymnastics that was developed from rhythmic so that it can be compared. The composition of movements that are delivered through the guidance of musical rhythms in producing body movements and artistic tools, characterizes this rhythmic gymnastics.

Rhythmic gymnastic is a complex sport. It is said to be complex because it consists of a combination of several elements including gymnastics, ballet, dance and apparatus manipulation [20]. In the competition, there are two types of competition, namely individual and group competition. Performance in the competition is assessed based on two judging panels, namely the level of difficulty and execution. Achievement in rhythmic gymnastics competition depends on the performance displayed by the athlete. Therefore, the provision of systematic and measurable training will be able to support achievement. This requires a coach to master the characteristics and training programs in rhythmic gymnastics.

\subsection{Rhythmic Gymnastics Training Program}

The success of an athlete's performance is determined by targeted training during specific periods, organization, management, and an athlete's individual adaptation to training and competition loads $[21,22]$. Rhythmic gymnastics is a sport that requires early athlete selection [23]. Elite athletes' programs in modern rhythmic gymnastics are becoming increasingly complicated: gymnasts must master many technically difficult elements in the early stages of specialization, on the basis of which their original programs and compositions can be built, and which can help express an athlete's individuality [24]. This shows that the training program applied to rhythmic gymnastics athletes greatly affects competitive performance. This is in line with several research results [25-27] which show that the exercise program applied is very effective. Based on this statement, it can be said that every rhythmic gymnastics coach must understand the training program to support the achievement of optimal performance in athletes. 


\section{Material \& Methodology}

\subsection{Data}

Data collection is the process of procuring data for research purposes. In this study, researchers used multiple-choice test instruments with four answer options, namely a, b, c, d, as a data collection technique.

\subsection{Method}

This research is descriptive quantitative. The method used in this study is the survey method with data collection techniques using tests. Survey Method is a joint research conducted with many subjects, intended to gather opinions or information about the status of symptoms at the time of the study.

\section{Results and Discussion}

\subsection{Results}

The results of the study of the knowledge level of rhythmic gymnastics coaches in the rhythmic gymnastics training program in the Province of Yogyakarta Special Region as a whole are measured by the question of multiple choice (multiple choice) which amounts to 20 items.

\subsection{Statement of results}

TABLE 1: Description of Sports Teacher Knowledge Level Research Results, Rhythmic Gymnastics Coach

Interval
$76 \%-100 \%$
$56 \%-75 \%$
$40 \%-55 \%$
$<40 \%$

\begin{tabular}{|c|c|}
\hline Category & Amount \\
\hline Excellent & 13 \\
\hline Enough & 10 \\
\hline Not Good Enough & 1 \\
\hline Not Good & 0 \\
\hline & $\mathbf{2 4}$ \\
\hline
\end{tabular}

Percent (\%)

54,2

41,7

4,2

0

Amount

24

100 


\subsection{Explanatory Text}

Based on the table and pictures above known the level of knowledge of rhythmic gymnastics coaches in the rhythmic gymnastics training program in Yogyakarta Special Region Province in the excellent category of $54.2 \%$, at $41,7 \%$, in the class is not good at $4.2,2 \%$, and in the category is not good at $0 \%$. These results can be interpreted that the level of knowledge of rhythmic gymnastics coaches in the Special Region province of Yogyakarta in rhythmic gymnastics training programs is mostly good. The story of rhythmic gymnastics coach knowledge in the rhythmic gymnastics program in this study is based on two factors, namely the exercise program and the periodization of exercise.

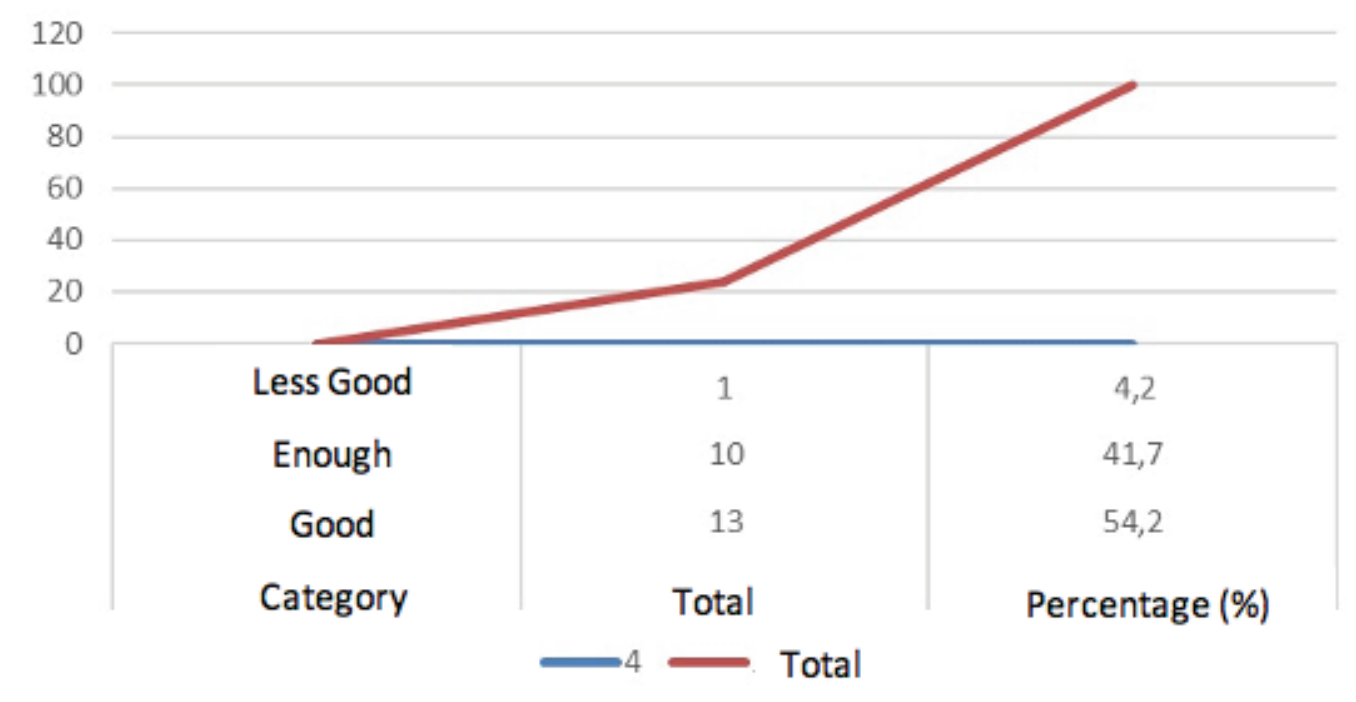

Figure 1: Knowledge Level Sports teacher, Gymnastics Coach

\subsection{Discussion}

The purpose of this research is to find out the level of knowledge of rhythmic gymnastics coaches in the Special Region of Yogyakarta. Based on the results of the study obtained the knowledge level of rhythmic gymnastics coaches in the rhythmic gymnastics program of Yogyakarta Special Region in the excellent category of $54.2 \%$, in the category of enough $41,7 \%$, in the category of less good by $4.2 \%$, and in the category of not good by $0 \%$. The results showed that rhythmic gymnastics coaches in the Special Region Province of Yogyakarta are still classified as having good training program knowledge. The percentage figure is $4.2 \%$ who have insufficient knowledge. The results of this study are in line with research conducted by [28]. [17] which showed that the understanding of trainers in Pati Regency regarding the training program was at an excellent level. 
The poor an knower is shown from most rhythmic gymnastics coaches in the Special Region Province of Yogyakarta. Answered questions on the periodization factor of the exercise, especially about the competition stage and the transition stage. In the general preparation stage, particular preparation stage, and pre-competition stage, some coaches have not correctly answered the question, but not as much as the competition stage and transition stage.

Coaches who are the subject of research have a variety of backgrounds, some coming from academics, from practitioners, and generals who are then appointed as coaches despite the coach's lack of knowledge in the game but the coach's knowledge in making training programs are still lacking. In comparison, the achievements of athletes are also determined by how smart and observant the coach can read the opportunities that his athletes have. As a coach also have to understand and be good at making training programs well.

In contrast to the knowledge factor of the training program, more than half of rhythmic gymnastics coaches in Yogyakarta Province can answer questions correctly. Especially when it comes to the understandings surrounding the training program and the principles of exercise. Knowledge and understanding of the exercise program is very important in gymnastics. This understanding must be shared by all teachers or trainers. Previous research conducted by Lacordia et.al [29] showed that the group of athletes who used training periodization programme showed more effective results compared to the group of athletes who trained without training periodization programme. $M$ explains three ways of acquiring teaching knowledge: academic, professional, and experience. In modern times, understanding of rhythmic gymnastics training programs is obtained based on the results of knowledge searches from various sources, one of which is communication media and media of the time. For example, coaches seek knowledge of exercise programs and exercise principles from the internet, books, or exchange thoughts with coach friends when meeting in any event. In preparing gymnastics coaches to be better prepared in the world of coaching, the Institute of Higher Education as if sports needed to organize extension programs as well as courses for gymnastics training. Sports institutions will provide independent, competent, ethical, critical, creative, and professional activities. In the process of extensions and procedures, prospective coaches will be provided with knowledge, training process, and evaluation applied in the field.

From the results of the research and the description of the discussion above, we can presume that as a good coach is not only required to know but should be able to get to the stage of evaluating the mistakes that exist and justify it. If the coach is never 
satisfied with the knowledge that has been obtained and can apply it well, it is not impossible that the achievements that have been achieved can be further improved.

\section{Conclusion}

Based on the results of research and discussion known the level of knowledge of sports teachers, rhythmic gymnastics coaches in Yogyakarta Special Region Province in a rhythmic gymnastics training program that is a useful category of $54.2 \%$. The class is quite $41,7 \%$, the type is not acceptable by $4,2 \%$, and the variety is not permitted by $0 \%$. The results can be concluded that the level of knowledge of rhythmic gymnastics coaches in the Province of Yogyakarta Special Region in the rhythmic gymnastics training program is acceptable

\section{Acknowledgement}

This research is fully supported by Affiliation Research Grant.

\section{References}

[1] Boligon L, Deprá PP, Rinaldi IPB. Influência da flexibilidade na execução de movimentos da ginástica rítmica. Acta Scientiarum - Health Sciences. 2015;37(2):141145. https://doi.org/10.4025/actascihealthsci.v37i2.21615

[2] Montosa I, Vernetta M, López-Bedoya J. Assessment of health-related fitness by the ALPHA-fitness test battery in girls and adolescents who practise rhythmic gymnastics. Journal of Human Sport and Exercise. 2018;13(1):188-204. https://doi. org/10.14198/jhse.2018.131.18

[3] Senatore B, Pisapia F, Di Domenico F. Menstrual cycle disorders in rhythmic gymnastics athletes. Journal of Physical Education and Sport. 2019;19(5):2005-2010. https://doi.org/10.7752/jpes.2019.s5299

[4] Di Cagno A, Battaglia C, Fiorilli G, et al. Motor learning as young gymnast's talent indicator. Journal of Sports Science and Medicine. 2014;13(4):767-773.

[5] Wang X, Marincola FM. A decade-plus of translation: What do we understand? Clinical and Translational Medicine. 2012;1(1):3. https://doi.org/10.1186/2001-1326-1-3

[6] Rutkowska-Kucharska A, Szpala A, Jaroszczuk S, Sobera M. Muscle coactivation during stability exercises in rhythmic gymnastics: A two-case study. Applied Bionics and Biomechanics. 2018:1-8. https://doi.org/10.1155/2018/8260402 
[7] Root H, Marshall AN, Thatcher A, Snyder Valier AR, Valovich McLeod TC, Curtis Bay R. Sports specialization and fitness and functional task performance among competitive youth gymnasts. Journal of Athletic Training. 2019;54(10):1095-1104. https://doi.org/ 10.4085/1062-6050-397-18

[8] Shigeta TT, Leahy AA, Smith JJ, Eather N. Lubans DR, Hillman CH. Cardiorespiratory and muscular fitness associations with older adolescent cognitive control. Journal of Sport and Health Science. 2020;10(1):82-90. https://doi.org/10.1016/j.jshs.2020.05. 004

[9] Devecioglu S, Sahan H, Tekin M, Yildiz M. Development of innovation strategies for sports education. Procedia-Social and Behavioral Sciences. 2012;46:445-449. https://doi.org/10.1016/j.sbspro.2012.05.139

[10] Leandro C, Ávila-Carvalho L, Sierra-Palmeiro E, Bobo-Arce M. Judging in rhythmic gymnastics at different levels of performance. Journal of Human Kinetics. 2017;60(1):159-165. https://doi.org/10.1515/hukin-2017-0099

[11] Miletić D, Katić R, Maleš B. Some anthropologic factors of performance in rhythmic gymnastics novices. Collegium Antropologicum. 2004;28(2):727-737.

[12] Fernandez-Villarino MA, Bobo-Arce M, Sierra-Palmeiro E. Practical skills of rhythmic gymnastics judges. Journal of Human Kinetics. 2013;39(1):243-249. https://doi.org/ 10.2478/hukin-2013-0087

[13] Donti O, Bogdanis GC, Kritikou M, Donti A, Theodorakou K. The relative contribution of physical fitness to the technical execution score in youth rhythmic gymnastics. Journal of Human Kinetics. 2016;50(2):143-152. https://doi.org/10.1515/hukin-20150183

[14] Fernandez-Villarino MA, Sierra-Palmeiro E, Bobo-Arce M, Lago-Peñas C. Analysis of the training load during the competitive period in individual rhythmic gymnastics. International Journal of Performance Analysis in Sport. 2015;15(2):660-667. https: //doi.org/10.1080/24748668.2015.11868822

[15] Agostini BR, Palomares EMDG, Andrade RDA, Uchôa FNM, Alves N. Analysis of the influence of plyometric training in improving the performance of athletes in rhythmic gymnastics. Motricidade. 2017;13(2):71-80. https://doi.org/10.6063/motricidade.9770

[16] Palomares BRA, De Godoy Palomares EM, Uchoa FNM, De Almeida Andrade R, Deana NF, Alves N. Effectiveness of the conjugate influence method in improving static and dynamic balance in rhythmic gymnastics gymnasts. Journal of Physical Education and Sports. 2019;19:1407-1417. 
[17] Baghurst T, Benham RH. Quality sport coaching in action: The application of the national standards for sport coaches in the interscholastic sport context. Strategies. Journal for Physical and Sport Educators. 2020;33(6):21-27. doi:10.1080/08924562.2020.1812340

[18] Hastria E. Peranan psikologi olahraga dalam meningkatkan prestasi atlet. Jurnal IImu Pengetahuan Sosial (Nusantara). 2016;1:22-30.

[19] Mahendra A. Permainan anak dan aktivitas ritmik. Universitas Terbuka; 2008.

[20] Gateva M. Tests to determinate the fitness level in rhythmic gymnastics. Sport Mont. 2015;43-45:63-70.

[21] Torrents C, Perl J, Schöllhorn W, Balague N. Quantitative and qualitative load optimization in strength training with the Per Pot Metamodel. Proceedings of the 6th Annual Congress of the European College of Sport Science Perspectives and Profiles $5^{\text {th }}-8^{\text {th }}$ July 2017, MetropolisRuhr, Germany. Sport \& Buch Strauss. 2001:1059.

[22] Mester J, Perl J. Grenzen der anpassungs - Und leistungsfahigkeit des menchen aus systematischer sicht: Zeitreihenanalyse und ein informatisches metamodell zur untersuchung physologischer adaptionsprozesse. Leistungssport. 2000;1:43-51.

[23] Balyi I. Sport system building and longterm athlete development in British Columbia. Sports Medicine Council of British Columbia; 2001. Available from https://citeseerx. ist.psu.edu/viewdoc/download?doi=10.1.1.1058.7920\&rep=rep1\&type=pdf

[24] Knoll K, Knoll K, Kothe T. Grenzen der leistungsfahigkeit des menschen in den technisch-kompositorischen sportarten. Leistungssport. 2000;1:33-38.

[25] Batista A, Gomes T N, Rui G, Calvarho L A. Training intensity of group in rhythmic gymnastics. Science, Movement and Health. 2018;18(1):17-24.

[26] Rutkauskaite R, Skarbaliu A. Models and interaction of intensive training and sport performance of 14-15 year old athletes in rhythmic gymnastics. SPORTAS Nr. 2012;4(87):57-64.

[27] Rutkauskaite R, Skarbaliu A. Training and sport performance of the 11-12 year old athletes in rhythmic gymnastics. SPORTAS Nr. 2009;1(72):107-115.

[28] Tustianti R, Nasuka N, Sulaiman S. Evaluation of gymnastics sports development in Pati Regency. Journal of Physical Education and Sports. 2020;9(1):71-75.

[29] Lacordia RC, Godoy ES, Vale RGS, Araujo CAS, Dantas EHM. Periodize training programme and technical performance of age-group gymnasts. International Journal of Sports Science \& Coaching. 2011;6(3):387-398. 